\title{
Cloning, expression and characterization of a pectate lyase from Paenibacillus sp. 0602 in recombinant Escherichia coli
}

\author{
Xiaoman $\mathrm{Li}^{1 \dagger}$, Huilin Wang ${ }^{1 \dagger}$, Cheng Zhou ${ }^{2}$, Yanhe Ma ${ }^{2 *}$, Jian $\mathrm{Li}^{3}$ and Jiangning Song ${ }^{1,4^{*}}$
}

\begin{abstract}
Background: Biotechnological applications of microbial pectate lyases (Pels) in plant fiber processing are considered as environmentally friendly. As such, they become promising substitutes for conventional chemical degumming process. Since applications of Pels in various fields are widening, it is necessary to explore new pectolytic microorganisms and enzymes for efficient and effective usage. Here, we describe the cloning, expression, characterization and application of the recombinant Pel protein from a pectolytic bacterium of the genus Paenibacillus in Escherichia coli.

Results: A Pel gene (pe/N) was cloned using degenerate PCR and inverse PCR from the chromosomal DNA of Paenibacillus sp. 0602. The open reading frame of pel $\mathbf{N}$ encodes a 30 amino acid signal peptide and a 445 amino acid mature protein belonging to the polysaccharide lyase family 1 . The maximum Pel activity produced by $E$. coli in shake flasks reached $2,467.4 \mathrm{U} \mathrm{mL}^{-1}$, and the purified recombinant enzyme exhibits a specific activity of 2,060 $\mathrm{U}$ $\mathrm{mg}^{-1}$ on polygalacturonic acid (PGA). The maximum activity was observed in a buffer with $5 \mathrm{mM} \mathrm{Ca}^{2+}$ at $\mathrm{pH} 9.8$ and $65^{\circ} \mathrm{C}$. PelN displays a half-life of around $9 \mathrm{~h}$ and $42 \mathrm{~h}$ at $50^{\circ} \mathrm{C}$ and $45^{\circ} \mathrm{C}$, respectively. The biochemical treatment achieved the maximal reduction of percentage weight (30.5\%) of the ramie bast fiber.
\end{abstract}

Conclusions: This work represents the first study that describes the extracellular expression of a Pel gene from Paenibacillus species in E. coli. The high yield of the extracellular overexpression, relevant thermostability and efficient degumming using combined treatments indicate its strong potential for large-scale industrial production.

Keywords: Pectate lyase, High-level expression, Characterization, Degumming

\section{Background}

Pectinases have various important applications in plant fiber processing, especially in textile, paper, fruit juice, coffee, and tea fermentation industries [1,2]. Depending on the mode of action and substrate specificity, pectinases involved in such biotechnological interventions can be classified into three major groups: protopectinases, pectinesterase (EC 3.1.1.11), and pectin depolymerases [3]. Among the pectin depolymerases, pectate lyase (Pel, EC 4.2.2.2) has attracted a great

\footnotetext{
* Correspondence: mayanhe@im.ac.cn; Jiangning.Song@monash.edu ${ }^{\dagger}$ Equal contributors

${ }^{2}$ State Key Laboratory of Microbial Resources, Institute of Microbiology, Chinese Academy of Sciences, Beijing 100101, China

${ }^{1}$ National Engineering Laboratory for Industrial Enzymes and Key Laboratory of Systems Microbial Biotechnology, Tianjin Institute of Industrial Biotechnology, Chinese Academy of Sciences, Tianjin 300308, China Full list of author information is available at the end of the article
}

deal of interest in the past few decades from both scientific and commercial perspectives. Pel is capable of cleaving $\alpha-1,4$ linkages in pectate polymers by $\beta$-elimination mechanism, producing 4,5-unsaturated oligogalacturonates [4]. Pectin, composed of partially methylesterified pectate, is more commonly used as a natural substrate in fiber crop degumming and retting processes, as it is an essential component in the middle lamella and the primary cell wall of higher plants [5]. Therefore, Pels that are capable of depolymerizing methylesterified substrates are more useful for industrial application. For instance, in textile processing, a crucial step for successful scouring of fabric is wax and pectin removal [6], which is generally performed under high temperature and high alkaline conditions that cause serious environment impacts and raw material loss. Therefore, it is desirable to develop Pels with high thermostability and alkalistability, which can be



(c) 2014 Li et al.; licensee BioMed Central Ltd. This is an Open Access article distributed under the terms of the Creative Commons Attribution License (http://creativecommons.org/licenses/by/2.0), which permits unrestricted use, distribution, and reproduction in any medium, provided the original work is properly credited. The Creative Commons Public Domain Dedication waiver (http://creativecommons.org/publicdomain/zero/1.0/) applies to the data made available in this article, unless otherwise stated. 
used as the ideal candidates for both commercially viable and environmentally responsible bioprocesses.

Pectolytic enzymes are ubiquitous in nature, and most of the Pels previously reported have been isolated from microorganisms such as bacteria and fungi [7]. Industrial applications of bacterial alkaline Pels, the majority of which occur in the Bacillus and Pseudomonas genus, have been extensively studied $[1,3]$. However, in terms of practical bioprocesses, only a few of them are robust enough to undergo long-time bioprocess treatment. Recently, enzymes originating from thermophilic or alkaliphilic microorganisms are garnering more interest [8-10] because of their good performance at extreme temperature or $\mathrm{pH}$. Although only limited information on the alkaliphilic strains of Paenibacillus spp. exists, several Pels from this genus have proved to be highly stable [10-12]. Hence, these bacteria have great potential for industrial-scale production of novel enzymes with desirable compatibility between the optimal temperature/pH and the extended useful life.

In the present study, we cloned the gene of a Pel (PelN) from Paenibacillus sp. 0602 isolated and identified from high alkaline soil based on its capacity of producing Pel. The biochemical properties of the recombinant PelN were comprehensively studied, which suggested its tolerance to high temperature, alkaline condition, and methylated substrates. The production of the recombinant PelN was accomplished in an efficient Escherichia coli secretory expression system, which achieved the highest yield in shake flasks reported so far with a high secretion capability. The biochemical degumming experiments of PelN suggested its favourable efficiency in ramie fiber bast degumming and various potential applications in biotechnology processes, especially in textile industry.

\section{Results}

\section{Sequence analysis}

A DNA fragment of 128 bp was obtained in degenerate PCR. The subsequent BLAST search in GenBank suggested that this fragment was a part of a Pel gene. The assembly of this fragment with the sequence obtained in inverse PCR with specific primers of this fragment produced a nucleotide of 2740 bp which consisted of the complete ORF of a Pel gene (pelN) and its flanking fragments. A putative promoter was predicted to be in the upstream region of the ORF, and the -35 and -10 regions were " 5 '-TTTACA-3'" and " 5 '-TATTAT-3'," respectively. A typical ribosomal binding site (5'-AGGAGG-3') was also located upstream of the ATG initial codon. In addition, in the downstream of the ORF, a rho-independent transcription terminator was also identified.

The deduced protein sequence of the ORF was found to have 475 amino acids, including a typical signal sequence cleaved by the type I signal peptidase (SPase I) [13]. The signal peptide of 30 amino acids comprised a positively charged N-domain with lysine and arginine residues, a hydrophobic $\mathrm{H}$-domain with 24 amino acids, and a SPase I cleavage site of three amino acids. It was found that the downstream residues of the signal peptide at the $\mathrm{N}$-terminus of the mature protein also contributed to the cleavage site recognition [14]. The consensus sequence G(Aro)a(3-7x)GG of Pels, which was predicted to form the cleavage signal at the mature protein side [15], was also present in the N-terminus of PelN in the form of G(Aro)a(6)GG. Analysis of the MSA of PelN and other Pels with solved structures from the PL1 family identified three conserved sequence patterns and a set of invariant amino acids located within the PelN peptide (Figure 1). The conserved sequence patterns used to characterize a novel sequence as a Pel are AxDIKGxxxxVTxS, vWiDH, and VxxRxPxxRxGxxHxxxN [15]. The invariant amino acids involved in catalytic function mainly comprised the catalytic residues $\mathrm{R} 275$, K244, and $\mathrm{R} 280$, and the $\mathrm{Ca}^{2+}$-binding residues D151, D173, and D177 in PelN. Six single mutants of these key residues, obtained by site-directed mutagenesis, resulted in almost completely inactive proteins, as shown in [Additional file 1].

According to the CAZy database (http://www.cazy. org/Polysaccharide-Lyases.html, accessed in December 2013), Pels occur within five PL families: PL1, PL2, PL3, PL9, and PL10. The BLAST (blastp) search against the NCBI database indicated that PelN is the closest to the PL1 family sequences. The deduced amino acid sequence of PelN exhibited $67-90 \%$ identity with the corresponding amino acid sequences from the same genus (YP_005074750, WP_007428224, WP_010348601, WP_017425629, WP_002622431 and ADB78775).

\section{Expression and purification of PelN}

PelN without the signal sequence was successfully expressed in the recombinant E. coli BL21 (DE3) in shake-flask cultivation mode (Figure 2). Under the optimal induction condition in this case $(50 \mathrm{mM}$ isopropylthio- $\beta$ galactoside, $25^{\circ} \mathrm{C}$ ), the highest extracellular and total Pel activities reached 2,201.7 and 2,467.4 $\mathrm{U} \mathrm{mL}^{-1}$ after 42-h cultivation, respectively, with a high secretion capability of $89.2 \%$.

PelN was purified from the crude extract of $E$. coli BL21 (DE3) harbouring pET-pelN. The two-step purification resulted in a three-fold increase in purity with a yield of $29 \%$, and the purified protein had a specific activity of 2,060 $\mathrm{U} \mathrm{mg}^{-1}$ on PGA (Table 1). Furthermore, PelN generated a single electrophoretic band on the SDS-PAGE gel at $48 \mathrm{kDa}$, corresponding to the calculated molecular weight (Figure 3). 

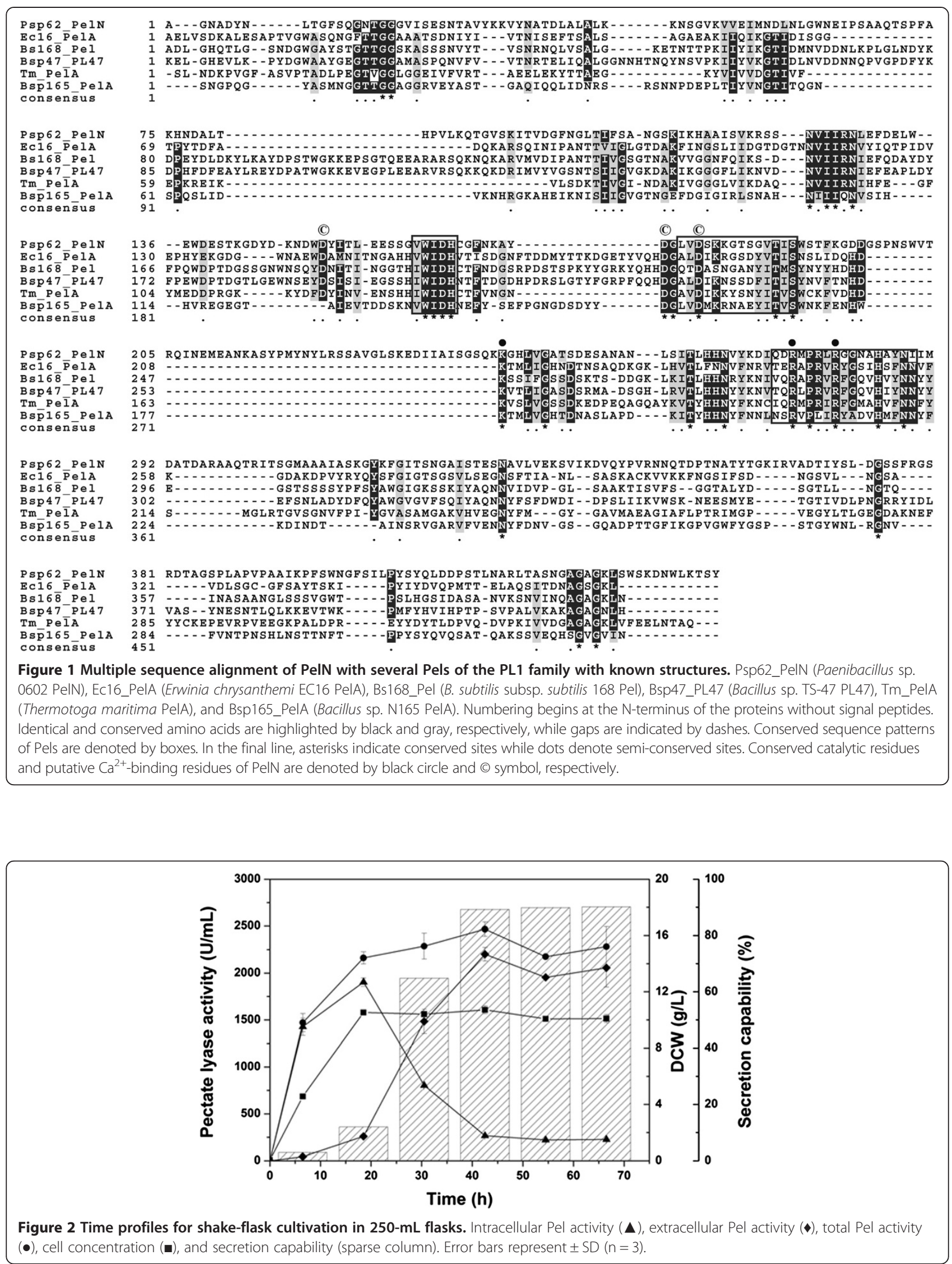
Table 1 Purification of the recombinant PelN from E. coli BL21 (DE3) *

\begin{tabular}{llllll}
\hline Fraction & Activity ${ }^{* *}(\mathbf{k U})$ & Protein $(\mathbf{m g})$ & Specific activity $\left(\mathbf{U ~ m g ~}^{-\mathbf{1}}\right)$ & Purification (fold) & Yield (\%) \\
\hline Crude extract of supernatant & $74.2 \pm 0.6$ & $109.8 \pm 0.9$ & $675.8 \pm 55.9$ & 1 & 100 \\
Ammonium sulphate precipitation & $46.6 \pm 6.2$ & $39.9 \pm 3.9$ & $1,166.5 \pm 59.8$ & 1.73 & 62.75 \\
UNOsphere S column & $21.5 \pm 0.1$ & $10.5 \pm 0.3$ & $2,060.0 \pm 71.1$ & 3.05 & 29.02 \\
\hline
\end{tabular}

*Data represent means $\pm S D(n=4)$ relative to the reference samples;

**The activity was measured on PGA under the standard conditions.

\section{Recombinant enzyme characterization Optimum $\mathrm{pH}$ and temperature}

The purified PelN displayed activity over a wide range of $\mathrm{pH}$ from 7.6 to 10.4 , with a maximum activity at $\mathrm{pH} 9.8$ (Figure 4a). The effect of temperature on the PelN activity was measured at the optimal $\mathrm{pH}$ of 9.8 and different temperatures ranging from 35 to $70^{\circ} \mathrm{C}$. The Pel activity increased gradually from $14.8 \%(682.8 \mathrm{U} / \mathrm{mg})$ at $35^{\circ} \mathrm{C}$ to the maximum of $100 \%(4629.2 \mathrm{U} / \mathrm{mg})$ at $65^{\circ} \mathrm{C}$ and then decreased sharply to $38.9 \%(1801.7 \mathrm{U} / \mathrm{mg})$ at $70^{\circ} \mathrm{C}$ and $18.0 \%(831.9 \mathrm{U} / \mathrm{mg})$ at $75^{\circ} \mathrm{C}$ (Figure $\left.4 \mathrm{~b}\right)$.

\section{The effects of different metal ions and chemicals}

The effects of various metal ions and chemicals were determined under the standard reaction condition. We found that PelN exhibited robust tolerance to several metal ions, and only $\mathrm{Ba}^{2+}$ caused a severe loss of activity (Table 2). On the other hand, Triton X-100 and Tween-

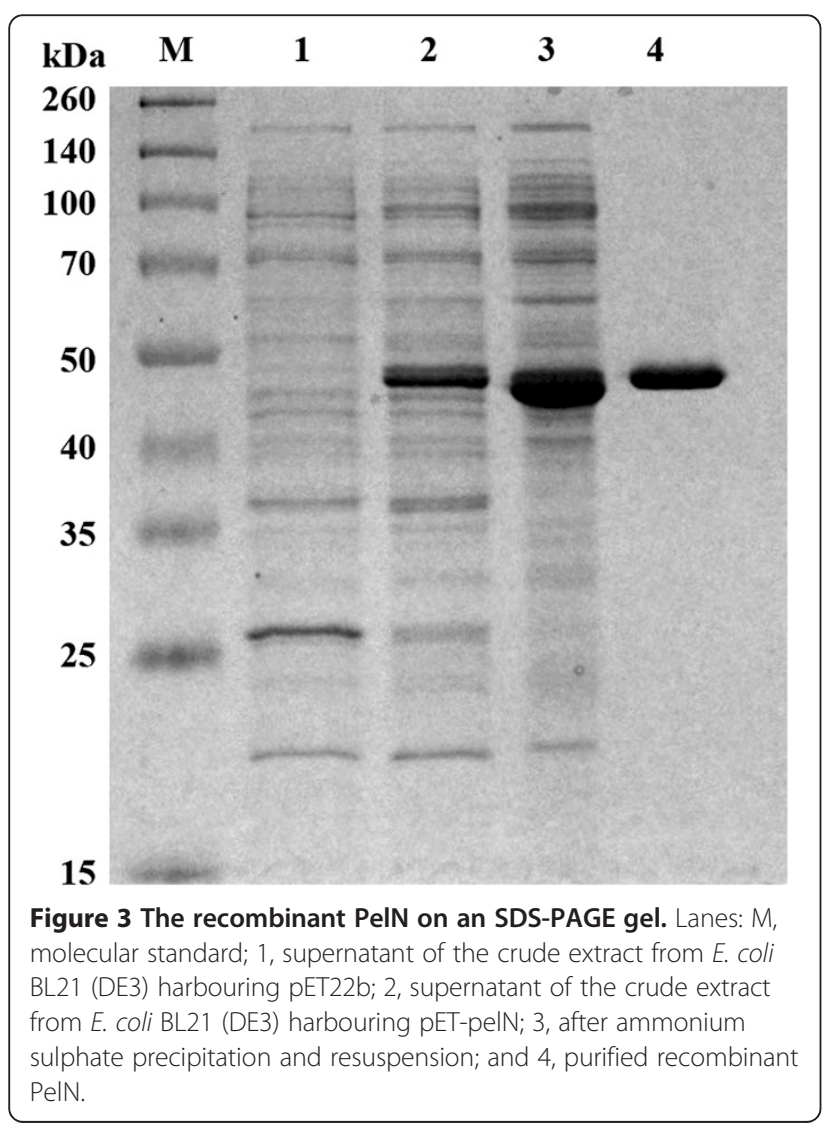

20 had negligible influence on the activity (Table 2). Similar to the majority of Pels, PelN required $\mathrm{Ca}^{2+}$ for its maximal activity. The presence of $0.5 \mathrm{mM} \mathrm{Ca}^{2+}$ in $\mathrm{PL}$ buffer (50 mM glycine- $\mathrm{NaOH}$ buffer, $\mathrm{pH} 9.8$ ) increased enzyme activity by more than 7 -fold, while no activity was detected with the addition of 0.5 and $1 \mathrm{mM}$ EDTA, indicating that $\mathrm{Ca}^{2+}$ plays an important role in the catalytic reaction of PelN. Hence, we also determined the optimal $\mathrm{Ca}^{2+}$ concentration (Figure 5). In particular, PelN activity was found to be considerably elevated with

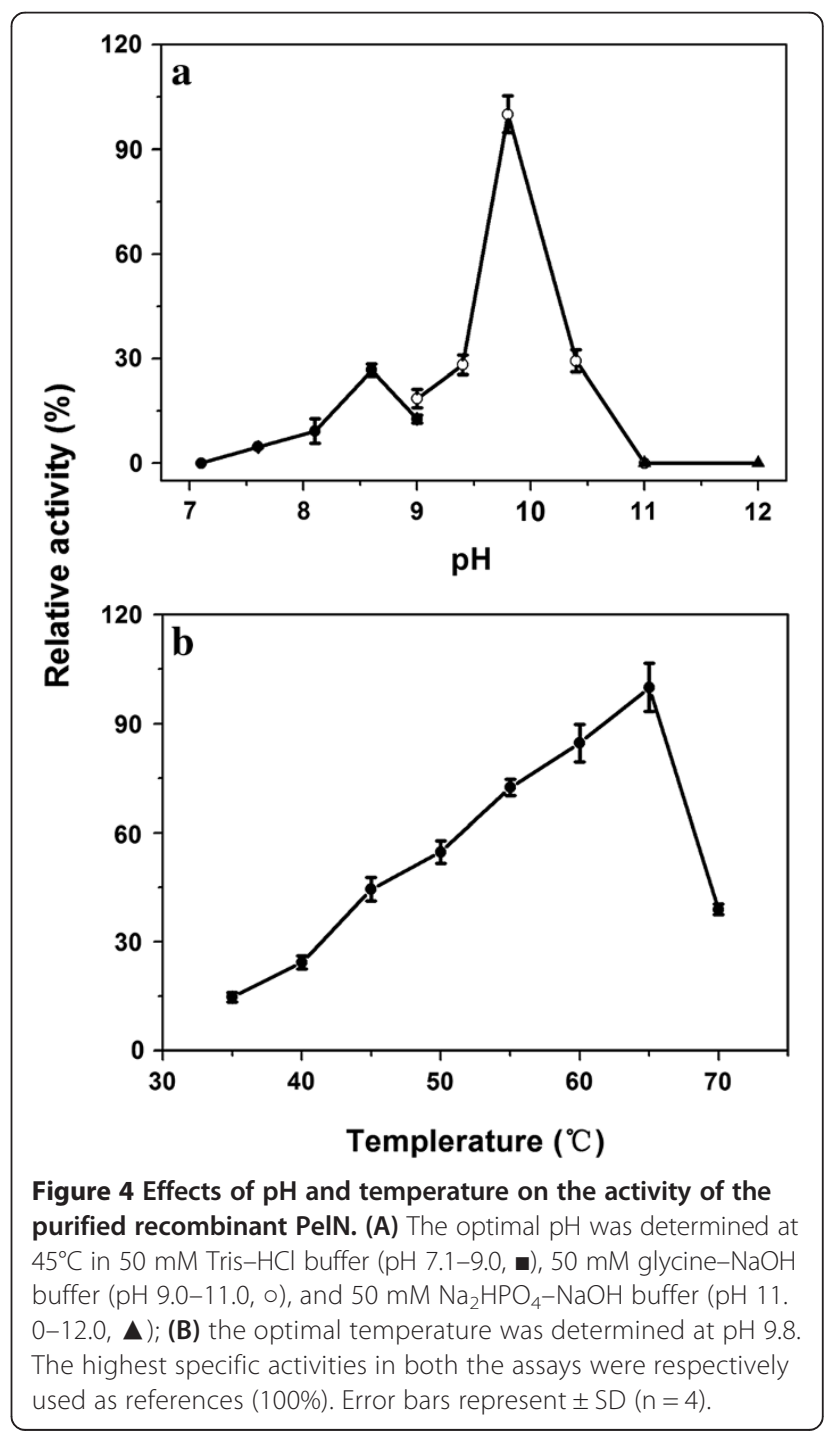


Table 2 Effects of different chemicals on the activity of the purified recombinant PeIN

\begin{tabular}{lll}
\hline Chemicals & \multicolumn{2}{l}{ Relative activity (\%)* } \\
\hline Concentration $(\mathrm{mM})$ & $\mathbf{0 . 5}$ & $\mathbf{1 . 0}$ \\
None & $100 \pm 1$ & $100 \pm 1$ \\
$\mathrm{Ca}^{2+}$ & $729 \pm 38$ & $437 \pm 1$ \\
$\mathrm{Mg}^{2+}$ & $125 \pm 11$ & $99 \pm 3$ \\
$\mathrm{Mn}^{2+}$ & $75 \pm 3$ & $57 \pm 5$ \\
$\mathrm{Cu}^{2+}$ & $79 \pm 3$ & $104 \pm 11$ \\
$\mathrm{Zn}^{2+}$ & $116 \pm 8$ & $106 \pm 7$ \\
$\mathrm{Fe}^{2+}$ & $82 \pm 7$ & $57 \pm 3$ \\
$\mathrm{Ba}^{2+}$ & $12 \pm 3$ & $3 \pm 0$ \\
$\mathrm{~K}^{+}$ & $119 \pm 8$ & $100 \pm 4$ \\
EDTA & $\mathrm{nd}$ & $\mathrm{nd}$ \\
Triton X-100 & $102 \pm 9$ & $100 \pm 8$ \\
Tween-20 & $98 \pm 2$ & $116 \pm 11$ \\
\hline
\end{tabular}

nd: no detectable activity.

*The activity under the standard conditions without any chemicals was used as the reference $(100 \%)$, and data represent means $\pm S D(n=4)$ relative to the untreated reference samples;

the addition of $0.1-2 \mathrm{mM} \mathrm{Ca}^{2+}$, but was inhibited at a high concentration of more than $5 \mathrm{mM} \mathrm{Ca}^{2+}$.

\section{Protein stability}

As the fiber degumming process could be accelerated under alkaline conditions [2], a favourable alkalistability of Pels is essentially required for many industrial processes. To explore this potential, the pH-dependent stability of the enzyme was further investigated by pre-incubation for $1 \mathrm{~h}$ at $45^{\circ} \mathrm{C}$ at varying $\mathrm{pH}$ values (Figure $6 \mathrm{a}$ ). The purified PelN was found to be stable over a $\mathrm{pH}$ range of 7.1-11.6 and was most stable at $\mathrm{pH}$ 11.0.

On the other hand, the long-term thermostability of Pels is a crucial aspect from the industrial perspective

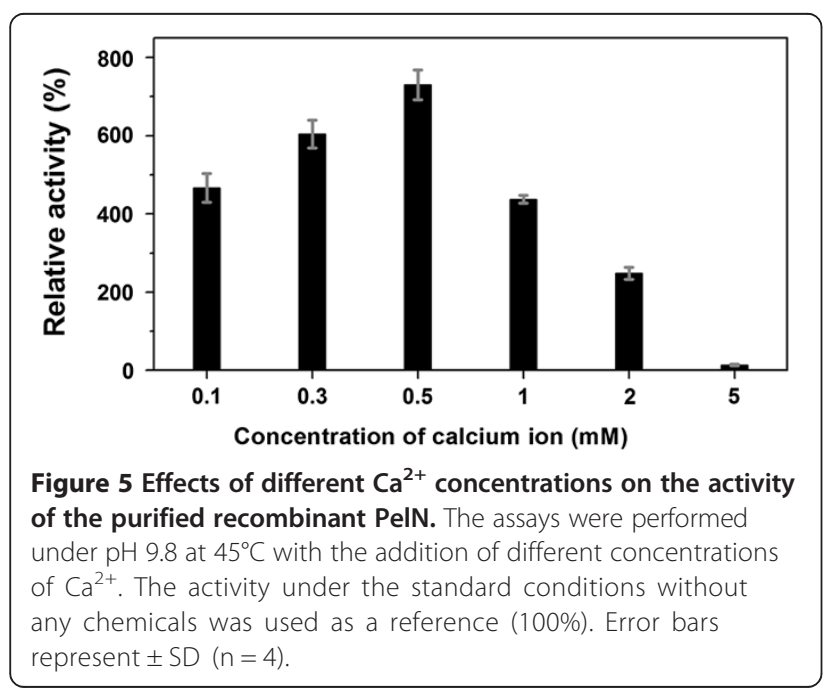

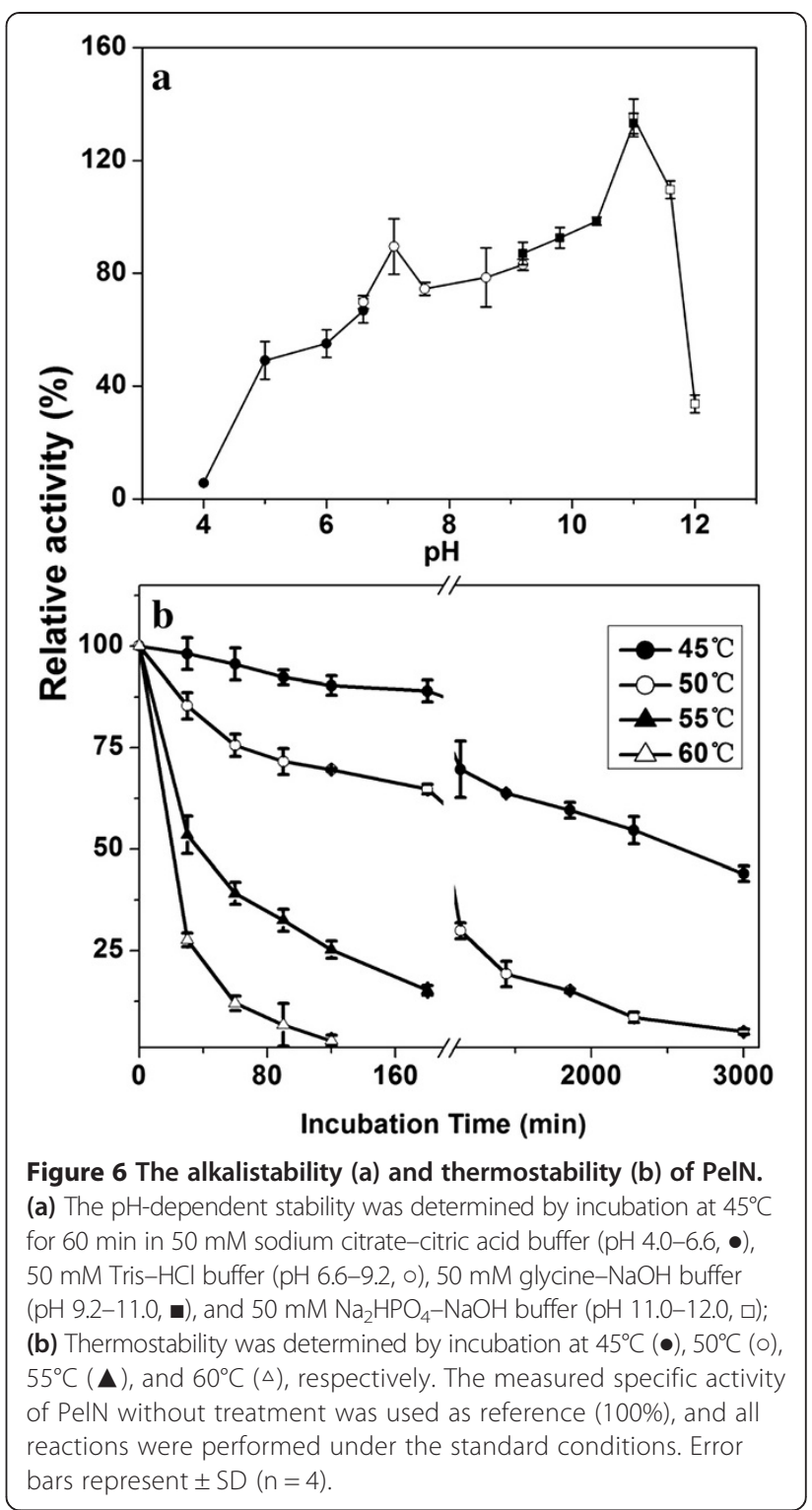

[16]. To investigate the effect of temperature on enzyme stability, PelN was incubated at different temperatures at $\mathrm{pH}$ of 9.8, and the samples were drawn at various time points. The results indicated that the recombinant PelN was considerably stable at 45 and $50^{\circ} \mathrm{C}$, with activities decreased to only 76.1 and $46.5 \%$, respectively, after 12 -h incubation. The half-life values of PelN were approximately $2,500 \mathrm{~min}$ at $45^{\circ} \mathrm{C}, 550 \mathrm{~min}$ at $50^{\circ} \mathrm{C}, 50 \mathrm{~min}$ at $55^{\circ} \mathrm{C}$, and $16.5 \mathrm{~min}$ at $60^{\circ} \mathrm{C}$, respectively (Figure $6 \mathrm{~b}$ ). The effect of temperature on protein structural stability was studied by carrying out the DSC experiment, and the melting temperature midpoint $\left(\mathrm{T}_{\mathrm{m}}\right)$ of the purified PelN was found to be $70.5^{\circ} \mathrm{C}$ (Figure 7). Besides, thermally induced denaturation was irreversible for PelN, as no detectable energy transition was observed in a second scan of the corresponding samples. 


\section{Substrate specificity}

The enzyme activities on pectins were also investigated under the standard condition. As shown in Table 3, PelN exhibited relatively high activity on methylated substrates. On pectin with relatively low degree (20-34\%) of methylation, the remaining specific activity of PelN was approximately $100 \%$ of that on PGA. High methylated pectin (55-70\%) resulted in slight inhibition of the PelN activity, which was still higher than $74 \%$.

Subsequently, the dependence of the enzyme reaction rate on substrate concentration was investigated under the standard conditions using PGA and both the types of pectins, respectively. The kinetic parameters of PelN were found to vary considerably on different substrates. The corresponding $V_{\max }$ of PelN on PGA was $4.12 \mathrm{~mol} \mathrm{mg}^{-1} \mathrm{~min}^{-1}$, which was 3.7 -fold higher than that on $20-34 \%$ methylated pectin, and 3.6-fold lower than that on highly methylated pectin. The affinity of PelN, indicated by $K_{m}$, for $20-34 \%$ methylated pectin, was lower than that for the other two substrates, whereas the catalytic efficiency, indicated by $k_{\text {cat }} / K_{m}$, on PGA was similar to that on low methylated pectin and was much higher than that on highly methylated pectin.

\section{Treatment of ramie bast fiber}

The enzymatic degumming processing of ramie fiber was optimised in terms of the enzyme dose at $50^{\circ} \mathrm{C}$. As shown in Figure 8, the unsaturated oligogalacturonic

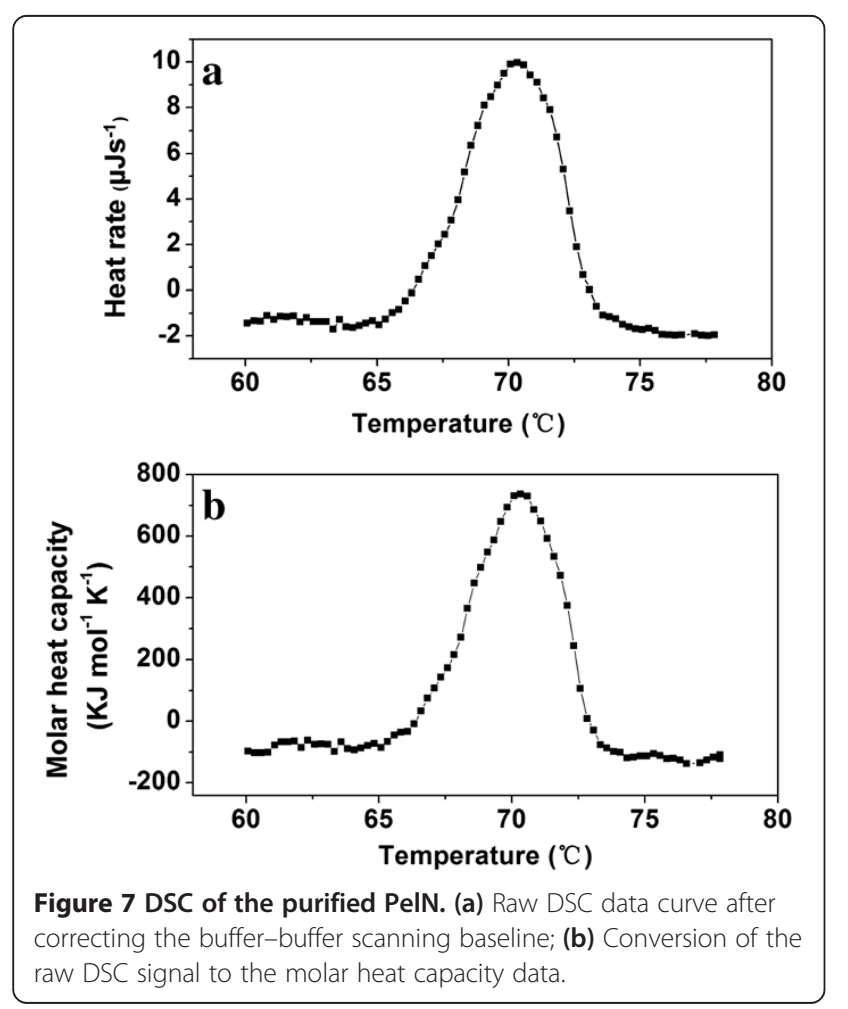

acid releasing peaked at $14.0 \mu \mathrm{mol} \mathrm{mL}^{-1}$ after 3-h treatment with $500 \mathrm{U} \mathrm{mL}^{-1}$ of PelN, and an increase in either enzyme dose or treatment time had no significant effect on the degumming reactions. However, when chemically pre-treated ramie fibers were subsequently treated with $500 \mathrm{U} \mathrm{mL}^{-1}$ of PelN at $50^{\circ} \mathrm{C}$, the unsaturated oligogalacturonic acid released reached $23.0 \mu \mathrm{mol} \mathrm{mL} \mathrm{L}^{-1}$ after 3-h of enzymatic treatment. Accordingly, the percent weight loss of ramie fiber treated by $500 \mathrm{U} \mathrm{mL}^{-1}$ of PelN and the combined biochemical method reached the maximums $(12.0 \%$ and 30.5\%) after 3-h of enzymatic treatment. Compared with chemical treatment, in which the percent weight loss of ramie fiber peaked at $19.0 \%$ after 6 -h of $2 \% \mathrm{NaOH}$ treatment at $90^{\circ} \mathrm{C}$, the combined biochemical method seemed to be more effective and economical. The fibers were also observed using an SEM, and the sample after biochemical treatment showed the smoothest surface in our experiments (Figure 9), suggesting that the gum-like material could be mostly removed by the combined method.

\section{Discussion}

In this study, the encoding gene of a Pel from a Paenibacillus strain previously isolated from high alkaline soil was cloned. Heterologously production of this protein was accomplished using the recombinant E. coli BL21 (DE3). Compared with the highest yield of Pel in E. coli previously reported by Fang et al. [17], the extracellular Pel production achieved in the present study exhibited an 8.54-fold increase, and the secretory capability increased from 69.3 to $89.2 \%$. Pels have also been expressed in other expression systems, such as B. subtilis $[18,19]$ and Pichia pastoris $[20,21]$, among which the highest yield reported previously was $2,138 \mathrm{U} \mathrm{mL}^{-1}$ in $B$. subtilis after 44-h cultivation in a 7.5-L fermentor [22]. This is 1.15fold lower than the production reported in this study. Moreover, compared with the B. subtilis expression system, the production of Pel using E. coli offers several important advantages. These include more reliable carriers of recombinant plasmids and no sporulation under stress conditions, which are propitious for largescale industrial production. The secretory expression strategy of PelN proposed in this study achieved a relatively higher secretion capability. This strategy has not only overcome the limitations of inclusion body formation, but also significantly simplified the downstream processing of this enzyme, as the fermentation broth could be directly used in fiber degumming.

Furthermore, biochemical properties of the recombinant PelN were also investigated in the present study. The optimal $\mathrm{pH}$ of this enzyme showed a similarity with the majority of alkaline Pels previously reported [7]. Nevertheless, except for a few hyperthermophilic Pels $[8,23]$, the optimal temperature $\left(65^{\circ} \mathrm{C}\right)$ of PelN was 
Table 3 Effects of different chemicals on the activity of the purified recombinant PelN*

\begin{tabular}{|c|c|c|c|c|c|c|}
\hline Substrate & & $\begin{array}{l}\text { Relative activity ** } \\
(\%)\end{array}$ & $\begin{array}{l}K_{m} \\
\left(\mathrm{~g} \mathrm{~L}^{-1}\right)\end{array}$ & $\begin{array}{l}V_{\max } \\
\left(\mathrm{mol} \mathrm{mg}^{-1} \min ^{-1}\right)\end{array}$ & $\begin{array}{l}k_{\text {cat }} \\
\left(s^{-1}\right)\end{array}$ & $\begin{array}{l}k_{\text {cat }} / K_{m} \\
\left(\mathrm{~L} \mathrm{~s}^{-1} \mathrm{~g}^{-1}\right)\end{array}$ \\
\hline PGA & & $100.0 \pm 4.2$ & $3.48 \pm 0.35$ & $4.12 \pm 0.77$ & $3.29 \times 10^{6}$ & $9.45 \times 10^{5}$ \\
\hline \multirow[t]{2}{*}{ Pectin } & $20-34 \%$ & $100.9 \pm 6.1$ & $15.06 \pm 1.24$ & $15.16 \pm 0.31$ & $1.21 \times 10^{7}$ & $8.03 \times 10^{5}$ \\
\hline & $55-70 \%$ & $74.3 \pm 2.6$ & $3.32 \pm 0.07$ & $1.15 \pm 0.09$ & $0.92 \times 10^{6}$ & $2.77 \times 10^{5}$ \\
\hline
\end{tabular}

*Data represent means $\pm S D(n=3)$ relative to the reference samples;

**The specific activity of PeIN on PGA under the standard conditions was used as the reference (100\%).

much higher than those of the common Pels from $P$. amylolyticus [12], Bacillus sp. [9] and B. subtilis 168 [24] $\left(40-50^{\circ} \mathrm{C}\right)$. Since a moderate temperature $\left(37-55^{\circ} \mathrm{C}\right)$ has often been applied in practical bioscouring processing, most of the enzymatic assays were carried out at 45 or $50^{\circ} \mathrm{C}$ in the present study, at which the relative activity was only $44.5 \%$ or $54.7 \%$ of the maximum, but was still practical.

The effect of calcium ions that play an important role in the activity of PelN was also investigated. On one hand, the activity of this enzyme was further elevated with the increase of $\mathrm{Ca}^{2+}$ concentration until apparent saturation was reached. On the other hand, the activity of PelN could not be detected in the presence of metal cation chelator. Zheng et al. [25] found that in crystals of different Pels of the PL1 family, the numbers of $\mathrm{Ca}^{2+}$ ions and the corresponding binding residues differed from each other. This suggests that the variety of the numbers of $\mathrm{Ca}^{2+}$-binding residues may be responsible for different modes of the calcium dependence of Pels. In the case of PelN, three aspartates (Asp ${ }^{151}$, Asp ${ }^{173}$, and Asp $^{177}$ ) were predicted to bind to two $\mathrm{Ca}^{2+}$ ions [Additional file 1] by MSA analysis (Figure 1). Moreover, Asp ${ }^{173}$ was found to have a more significant impact on the catalysis

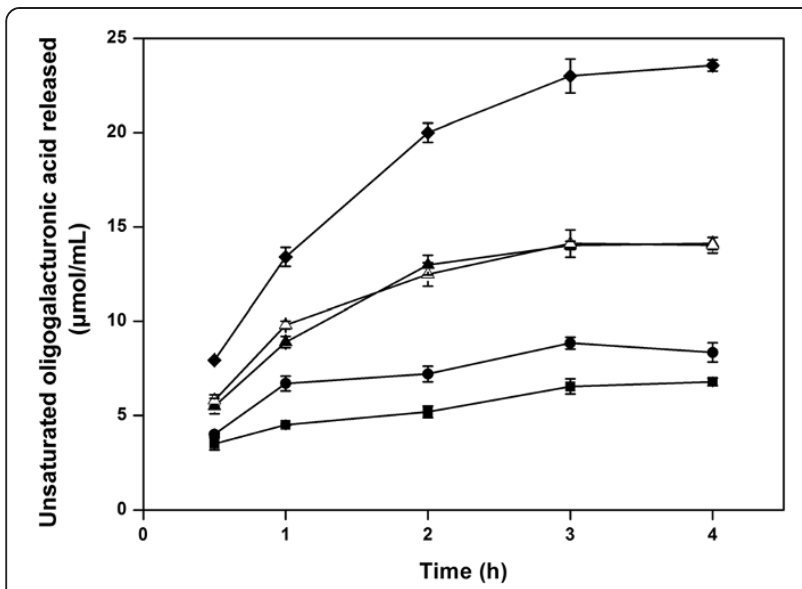

Figure 8 Unsaturated oligogalacturonic acid released from ramie bast fibers with different treatments. Ramie bast fibers were treated with $100 \mathrm{U} \mathrm{ml}^{-1}(\mathbf{\square}), 300 \mathrm{U} \mathrm{ml}^{-1}(\bullet), 500 \mathrm{U} \mathrm{ml}^{-1}(\mathbf{\Delta})$ and $700 \mathrm{U} \mathrm{ml}^{-1}(\Delta)$ of PelN, and $500 \mathrm{U} \mathrm{ml}^{-1}$ of PelN after pre-treatment of $2 \% \mathrm{NaOH}$ for $0.5 \mathrm{~h}(\bullet)$, respectively. Error bars represent $\pm \mathrm{SD}(n=3)$. than the other two aspartates, presumably due to its potential interaction with both $\mathrm{Ca}^{2+}$ ions. Similar $\mathrm{Ca}^{2+}$-binding mode, residues and dependence were also observed in Pel from a marine strain T. maritima [8]. As aspartates are capable of binding to several types of cations, addition of $\mathrm{Mg}^{2+}$ and $\mathrm{Zn}^{2+}$ could slightly enhance the enzyme activity. This phenomenon has been previously observed in other Pels, such as PelZ from E. chrysanthemi [26] and Pel22 from B. pumilus BS22 [27], when using various divalent cations as cofactors.

One of the most attractive properties of PelN is its robust thermo-alkalistability. In fiber bioscouring, alkaline environment and moderate temperature are required for effective degumming and fiber quality improvement. Therefore, enzyme stability under such conditions is a key property for commercially viable bioprocesses. Similar to most Pels, PelN showed maximum activity under alkaline conditions. Moreover, this protein was found to be very stable over a wide $\mathrm{pH}$ range and exhibited highest stability in stronger alkaline solution ( $\mathrm{pH}$ 11.0), thereby meeting the requirements of the textile industrial bioscouring processes. As a thermostable candidate, PelA from the hyperthermophilic bacterium T. maritima, with an optimal temperature of $90^{\circ} \mathrm{C}$ and 2-h halflife at $95^{\circ} \mathrm{C}$, has been found to be the most thermoactive Pel characterized to date [8]. Meanwhile, researchers have also made significant efforts to improve the thermostability of Pel. For example, sequence-based knowledge has provided potential amino acid substitutions for stability optimization of PelII from Xanthomonas campestris, leading to a 23-fold increase in its half-life $(1,292 \mathrm{~min})$ at $45^{\circ} \mathrm{C}$ [28]. As the half-life of PelN has been demonstrated to be longer than $41 \mathrm{~h}$ at $45^{\circ} \mathrm{C}$, it can be considered to be an ideal candidate for further engineering for large-scale industrial application when similar strategies are deployed.

Another notable feature of PelN is its activities on both PGA and various methylated pectins. It has been reported that the degree of methylation of naturally occurring pectins is about 70\% [7], thus making the robust activity of PelN on highly methylated substrates an attractive property for practical applications. To date, most of the reported Pels have been found to be capable of degrading PGA or low methylated substrates more efficiently than highly methylated pectins (> 22\%) [29-32]. 


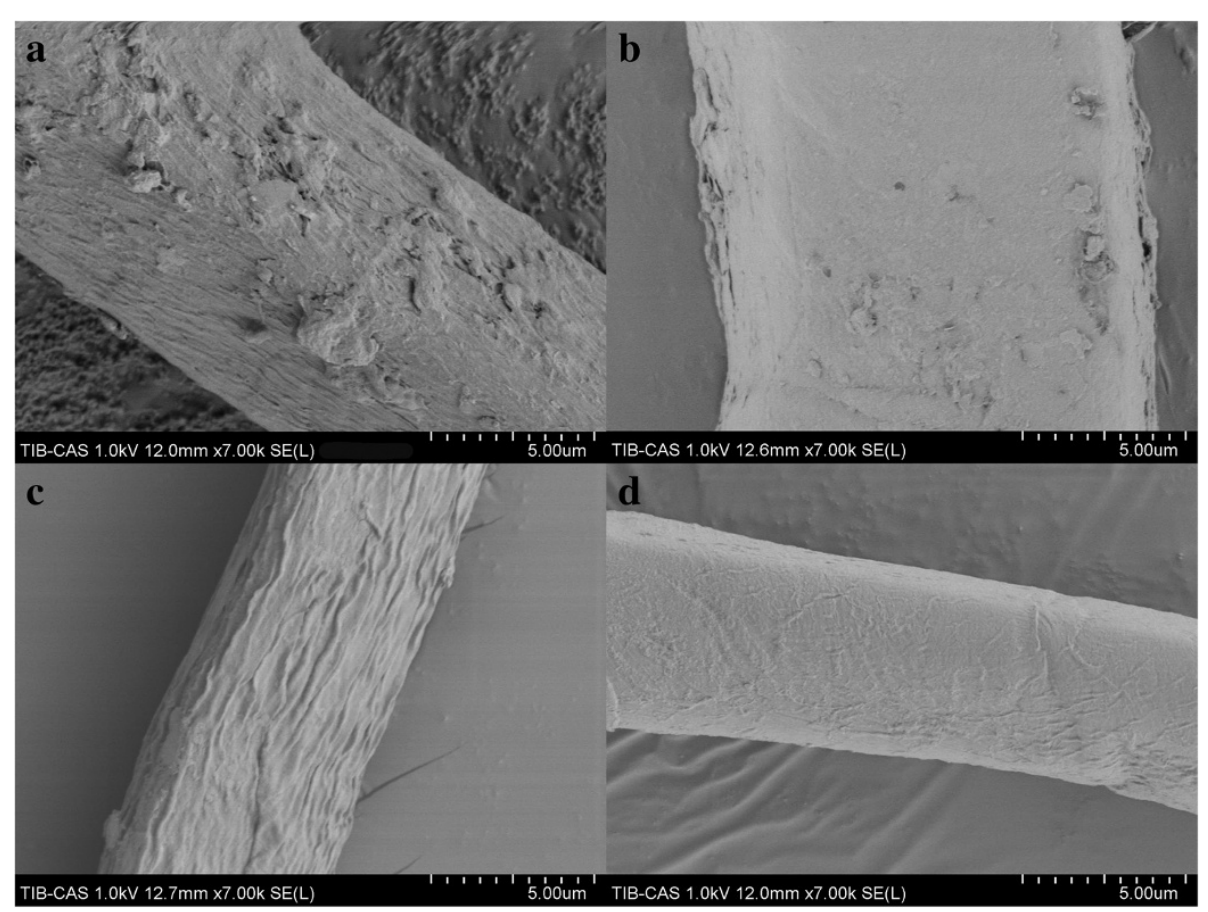

Figure 9 Scanning electron micrographs of ramie bast fibers. (a) PL buffer treated fibers (control); (b) PelN treated fibers; (c) $2 \% \mathrm{NaOH}$ treated fibers; (d) $2 \% \mathrm{NaOH}$ and subsequently PelN treated fibers.

Notably, PelN demonstrated a similar activity on PGA and $20-34 \%$ methylated pectin, and its activity on 55$70 \%$ methylated pectin remained $74 \%$. Comparison of the determined $K_{m}$ values of the recombinant PelN suggested that the enzyme exhibited an approximately 4.5-fold increase in the affinity for PGA and highly methylated pectin (55-70\%) than that for pectin with a low degree (20-34\%) of methylation. In contrast, the specificity constant $k_{\text {cat }} / K_{m}$ values of PelN decreased with the increasing degree of methylation of the substrate. It has been reported that the $K_{m}$ values of Pels from Bacillus sp. [9], B. licheniformis [5], X. campestris [28] and Streptomyces sp. S27 [33] on PGA range from 0.2 and $7.9 \mathrm{~g} \mathrm{~L}^{-1}$. Although the $K_{m}$ value determined for PelN on PGA falls within this range, it is much higher than those of other bacterial Pels $[5,9,28]$, indicating relatively lower substrate affinity. Interestingly, in the case of PelII from $X$. campestris [28], the $K_{m}$ value was reported to be only $0.98 \mathrm{~g} \mathrm{~L}^{-1}$, which was 3.6-fold lower than that of PelN, while the $k_{\text {cat }}$ value of PelII was much lower $\left(10^{4}\right.$-fold $)$ than that of PelN. Thus, the catalytic efficiency of PelN indicated by $k_{\text {cat }} / K_{m}$ was more favorable.

In the degumming experiments, the biochemical method developed in our research has proved to be more effective and milder than conventional chemical treatment. Moreover, the total processing time was reduced from $6 \mathrm{~h}$ to $3.5 \mathrm{~h}$. In earlier reports, the natural producers of Pels were used directly in the bio-degumming [34-36]. In such cases, inducible Pels and/or other pectin-degrading enzymes are secreted into the media by microorganisms, break down the pectin polymers and then provide nutrients for the producers [1]. The enzyme production and degumming occur in the same process; however, the processing time is significantly prolonged because of bacterial adaptation and the low yield of Pels in low-cost degumming media. For example, it took 28 and 48-h incubation of the alkaliphilic bacteria Bacillus sp. NT-39 and NT-76, respectively, to remove the gum of more than $5.0 \%$ of the fibers [34], and 24-h incubation of B. pumilus to cause the weight loss of the ramie fiber by $25 \%$ [36]. Degumming performed by enzymes from fermentation supernatant of recombinant producers was demonstrated to be more practical. Pel168 from the B. subtilis 168 was produced by recombinant $P$. pastoris, and used in ramie fiber degumming. The results showed that the textile lost $15 \%$ weight after 1 -h treatment and only suffered from a minimal detrimental effect for fibers [24]. Admittedly, chemical treatment outperforms enzymatic method in terms of gum removal rate. The combined treatment used in our experiments and other studies [36,37] was demonstrated to considerably reduce the consumption of chemicals and energy, thus making itself more economical and eco-friendly.

\section{Conclusions}

A pectate lyase gene from Paenibacillus sp. 0602 was cloned and overproduced in E. coli BL21 (DE3). The 
enzyme exhibited favourable alkalistability, with a maximum residual activity after incubation at $\mathrm{pH} 11.0$ for $1 \mathrm{~h}$, and showed promising thermostability, with the highest activity level at $65^{\circ} \mathrm{C}$ and long-term half-life at 45 and $50^{\circ} \mathrm{C}$. Furthermore, this enzyme was capable of maintaining high specific activities on methylated pectin. In ramie degumming processing, the combined biochemical method with the advantage of reduced process time and energy consumption was found to be a promising substitute to traditional alkaline treatment characterized by high pollution. These findings, together with its high production in the recombinant E. coli BL21 (DE3), highlight the industrial application potential of this enzyme as a key enzyme in mild and cost-effective bioresource industries in textile, paper-making, and pectic wastewater treatment.

\section{Methods}

\section{Strains and culture media}

Paenibacillus sp. 0602 was isolated from high alkaline soil in Bohai Gulf, and has been deposited in the China General Microbiological Culture Collection Centre (CGMCC No. 5696). E. coli BL21 (DE3) was used for recombinant protein expression, and was cultivated in modified Terrific broth (TB) medium (10 $\mathrm{g} \mathrm{L}^{-1}$ of glycerol, $24 \mathrm{~g} \mathrm{~L}^{-1}$ of yeast ex-

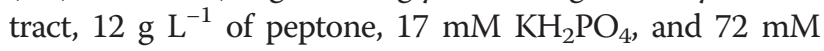
$\mathrm{K}_{2} \mathrm{HPO}_{4}$ ).

\section{Nucleic acid manipulation}

The chromosomal DNA of Paenibacillus sp. 0602 was prepared as previously described [38], which was subsequently used as the template in degenerate PCR and inverse PCR. Degenerate primers pel-F and pel-R were designed according to the conservative patterns "nviirN" and "v/iWiDH" of Pels with some modifications of those used by Wang et al. [39]. To clone the intact ORF of the pel gene and its flanking sequences, inverse PCR was performed using the method developed by Ochman et al. [40] with primers pel-inverse-F and pel-inverse-R. The PCR fragment of pel $\mathrm{N}$ without signal peptide encoding sequence was amplified with PCR using primers pelN-F and pel $\mathrm{N}-\mathrm{R}$, and inserted into the expression plasmid pET-22b $(+)$. The resulting plasmid pET-pelN was transformed into E. coli BL21 (DE3). Mutations were introduced using the QuickChange mutagenesis kit, and the mutagenic primers were designed according to the instruction given in the manual. All primers used in this manuscript are listed in [Additional file 2].

\section{Bioinformatic analysis}

Analysis of the product of degenerate PCR was performed using BLAST (http://www.ncbi.nlm.nih.gov/blast/). The sequence of the product of inverse PCR was respectively analyzed by using the ORF Finder (http://www.ncbi.nlm. nih.gov/gorf/gorf.html) [41] to identify the complete ORF, the PePPER webserver (http://pepper.molgenrug.nl/) [42] to predict the upstream elements, and the RibEx program (http://www.ibt.unam.mx/biocomputo/ribex.html) [43] to identify its transcription terminator. Deduction of amino acid sequence and calculation of molecular mass and isoelectric point of PelN were performed with the DNAMAN 5.0 software (Lynnon Biosoft, Quebec, Canada). The signal peptide was predicted with SignalP (http://www.cbs. dtu.dk/services/SignalP/) [44] specifically configured for gram-positive bacteria. To identify functional sites of PelN, the MSA of several Pels with solved structures from PL1 family without signal peptides was constructed using the MUSCLE program (http://www.ebi. ac.uk/Tools/msa/muscle/) [45].

\section{Protein expression and purification}

In shake-flask cultivation, the expression of recombinant PelN using E. coli BL21(DE3) was carried out as described previously [39]. The protein in the supernatant was concentrated by ammonium sulphate precipitation, resuspended in buffer A $(20 \mathrm{mM}$ sodium phosphate, $\mathrm{pH}$ 7.1), and dialyzed against the same buffer. After centrifugation at $15,000 \times \mathrm{g}$ for $1 \mathrm{~h}$ to remove cell debris and insoluble proteins, the supernatant was loaded to an UNOsphere S column (Bio-Rad) previously equilibrated against buffer $\mathrm{A}$, and eluted using a linear sodium chloride gradient from 0 to $500 \mathrm{mM}$. The active fractions were pooled and dialyzed against stock buffer $(50 \mathrm{mM}$ Hepes- $\mathrm{KOH}$ supplemented with $7 \mathrm{mM} \beta$-mercaptoethanol and 1 mM EDTA, pH 7.1).

SDS-PAGE analysis was performed using 10\% separating gel. After electrophoresis, the protein bands were visualized by Coomassie brilliant blue R-250 staining.

\section{Enzyme assays}

The purified proteins were used in enzyme assays. In the standard condition, the assay mixtures containing $2 \mathrm{~mL}$ of $0.2 \%(w / v)$ PGA in PL buffer $(50 \mathrm{mM}$ glycine- $\mathrm{NaOH}$ buffer, $\mathrm{pH}$ 9.8) supplemented with $0.5 \mathrm{mM} \mathrm{CaCl} 2$ were incubated for $15 \mathrm{~min}$ at $45^{\circ} \mathrm{C}$, and $3 \mathrm{~mL}$ of $50 \mathrm{mM}$ phosphoric acid was added immediately to terminate enzymatic reactions. The absorption at $235 \mathrm{~nm}$, indicating the formation of unsaturated products, was spectrophotometrically measured [21]. One unit of enzymatic activity was defined as the amount of enzyme that produced $1 \mu \mathrm{mol}$ of unsaturated product per minute under the above-mentioned assay conditions.

To characterize the biochemical properties of PelN, the influence of $\mathrm{pH}$, temperature, various chemicals, and substrates with different degrees of methylation was comprehensively investigated. The optimal $\mathrm{pH}$ of the purified recombinant PelN was determined at $45^{\circ} \mathrm{C}$ and a $\mathrm{pH}$ range of 7.1-12.0 using $50 \mathrm{mM}$ Tris $-\mathrm{HCl}$ buffer $(\mathrm{pH}$ 7.1-9.0), $50 \mathrm{mM}$ glycine- $\mathrm{NaOH}$ buffer $(\mathrm{pH} 9.0-$ 
11.0), and $50 \mathrm{mM} \mathrm{Na} \mathrm{HPO}_{4}-\mathrm{NaOH}$ buffer (pH 11.0-12.0), respectively. The optimal temperature was determined in PL buffer at different temperatures in the range of $35-70^{\circ} \mathrm{C}$. To analyze the effects of different metal ions and other chemicals on the activity of PelN, 0.5 and $1 \mathrm{mM} \mathrm{Mg}^{2+}, \mathrm{Mn}^{2+}, \mathrm{Cu}^{2+}, \mathrm{Zn}^{2+}, \mathrm{Fe}^{2+}, \mathrm{K}^{+}, \mathrm{Ba}^{2+}$, and $\mathrm{Ca}^{2+}$, as well as EDTA, Triton X-100, and Tween-20 were added to the PL buffer, respectively, and 0.2\% PGA $(\mathrm{w} / \mathrm{v})$ was used as the substrate. To investigate the influence of the substrate methylation on the activity of PelN, PGA was replaced with two types of pectins (Sigma) with low degree (20-34\%) and high degree (55-70\%) of methylation, respectively. To determine the kinetic parameters, the enzymes were incubated at $45^{\circ} \mathrm{C}$ with PGA or pectins at concentrations ranging from 0.05 to $1 \mathrm{~g} \mathrm{~L}^{-1}$.

\section{Stability measurement}

For the analysis of $\mathrm{pH}$-dependent stability, the enzyme was incubated at $45^{\circ} \mathrm{C}$ for $1 \mathrm{~h}$ at a $\mathrm{pH}$ range of 7.0-12.0 using $50 \mathrm{mM}$ sodium citrate-citric acid buffer $(\mathrm{pH} 4.0-$ 6.6), $50 \mathrm{mM}$ Tris- $\mathrm{HCl}$ buffer (pH 6.6-9.2), $50 \mathrm{mM}$ glycine$\mathrm{NaOH}$ buffer (pH 9.2-11.0), and $50 \mathrm{mM} \mathrm{Na}_{2} \mathrm{HPO}_{4}-\mathrm{NaOH}$ buffer ( $\mathrm{pH} 11.0-12.0)$, respectively. The residual activity of each sample was then measured under the standard assay condition. To determine the thermostability of PelN, the half-life of inactivation was measured using the following procedure: PelN was pre-incubated in PL buffer at 45, 50, 55 , and $60^{\circ} \mathrm{C}$, respectively. The samples were drawn at different time points and subjected to standard enzyme assays.

To perform the differential scanning calorimetry (DSC) experiments, the purified PelN enzymes were diluted to $0.2 \mathrm{~g} \mathrm{~L}^{-1}$ using $10 \mathrm{mM} \mathrm{Na}_{2} \mathrm{HPO}_{4}-\mathrm{NaOH}$ buffer ( $\mathrm{pH} 9.8$ ). Calorimetric measurements were carried out as described by Solbak et al. [46] with necessary modification. The DSC experiments were performed on a Nano DSC apparatus (TA Instruments, USA) with a scan rate of $36^{\circ} \mathrm{C} \mathrm{h}^{-1}$ at $1 \mathrm{~atm}$. The amount of heat absorbed or released during protein thermal denaturation was measured. The raw data were converted to an apparent molar heat capacity by correcting for the buffer-buffer scanning curve and dividing each data point by scan rate and the amount of proteins in the sample cell.

\section{Degumming and scanning electron microscopy of ramie bast fibers}

Degumming was performed according to Kapoor et al. [37] with certain modification. Decorticated ramie fibers were boiled in water for $15 \mathrm{~min}$, and then dried before treatments. Degumming of ramie bast fibers was carried out in 250-ml Erlenmeyer flasks containing $2 \mathrm{~g}$ of dried raw fibers. In chemical treatment, fibers were incubated in $100 \mathrm{~mL}$ of $2 \% \mathrm{NaOH}$ solution at $90^{\circ} \mathrm{C}$. To balance the activity and stability of PelN, the enzyme-involved treatments were carried out at $50^{\circ} \mathrm{C}$. In enzyme treatment, fibers were incubated in $100 \mathrm{~mL}$ of PL buffer (with $0.5 \mathrm{mM} \mathrm{CaCl}_{2}$ ) containing different doses of PelN. Controls were treated under the same condition without the addition of PelN. In the combined biochemical treatment, fibers were treated with $2 \% \mathrm{NaOH}$ solution at $90^{\circ} \mathrm{C}$ for $0.5 \mathrm{~h}$, washed with water twice and subsequently incubated with the optimised PelN dose $\left(500 \mathrm{U} \mathrm{mL}^{-1}\right)$ at $50^{\circ} \mathrm{C}$. In enzyme-involved treatments, the increase of absorbance at $235 \mathrm{~nm}$, indicating the releasing unsaturated oligogalacturonic acid from fibers, was measured to monitor the pectolytic processing.

Scanning electron microscopy (SEM) was performed to observe the variation of surface structures of differently treated fibers. The samples were prepared as described earlier [37], and then were observed under SEM (Hitachi SU8010, Japan).

\section{Nucleotide sequence accession number}

The DNA sequence of the pelN gene from Paenibacillus sp. 0602 has been deposited in the GenBank database under the accession number.

\section{Additional files}

\section{Additional file 1: Relative activities of the PelN mutants. \\ Additional file 2: Forward (-F) and reverse $(-\mathrm{R})$ primers used in PCRs and site-directed mutagenesis.}

\section{Competing interests}

The authors declare financial competing interests. The contents of this manuscript have been partially patented by Tianjin Institute of Industrial Biotechnology, Chinese Academy of Sciences (Application Number 201310155628.4).

\section{Authors' contributions}

$\mathrm{XL}$ carried out the cloning, the purification of PeIN, DSC experiment, degumming processing and SEM as well as drafted the manuscript. HW investigated the heterologous expression and the biochemical characterization of PelN protein. CZ offered valuable experimental protocols of the degumming processing. JL, YM and JS critically revised and corrected the manuscript. All authors have read and approved the final manuscript.

\section{Acknowledgements}

This work was supported by grants from the Hundred Talents Program of the Chinese Academy of Sciences (CAS), Knowledge Innovation Program of CAS (KSCX2-EW-G-8), Tianjin Municipal Science \& Technology Commission (10ZCKFSY05600), and National Health and Medical Research Council of Australia (NHMRC) (490989). JL is an NHMRC Senior Research Fellow. JS is an NHMRC Peter Doherty Fellow and a Recipient of the Hundred Talents Program of CAS.

\section{Author details}

${ }^{1}$ National Engineering Laboratory for Industrial Enzymes and Key Laboratory of Systems Microbial Biotechnology, Tianjin Institute of Industrial Biotechnology, Chinese Academy of Sciences, Tianjin 300308, China. ${ }^{2}$ State Key Laboratory of Microbial Resources, Institute of Microbiology, Chinese Academy of Sciences, Beijing 100101, China. ${ }^{3}$ Drug Delivery, Disposition and Dynamics, Monash Institute of Pharmaceutical Sciences, Monash University, Parkville Campus, 381 Royal Parade, Parkville, Victoria 3052, Australia. ${ }^{4}$ Department of Biochemistry and Molecular Biology and ARC Centre of Excellence in Structural and Functional Microbial Genomics, Faculty of Medicine, Monash University, Clayton, Victoria 3800, Australia. 
Received: 20 January 2014 Accepted: 4 March 2014

Published: 10 March 2014

\section{References}

1. Hoondal GS, Tiwari RP, Tewari R, Dahiya N, Beg QK: Microbial alkaline pectinases and their industrial applications: a review. Appl Microbiol Biotechnol 2002, 59(4-5):409-418.

2. Kashyap DR, Vohra PK, Chopra S, Tewari R: Applications of pectinases in the commercial sector: a review. Bioresour Technol 2001, 77(3):215-227.

3. Sarethy IP, Saxena Y, Kapoor A, Sharma M, Sharma SK, Gupta V, Gupta S: Alkaliphilic bacteria: applications in industrial biotechnology. J Ind Microbiol Biotechnol 2011, 38(7):769-790.

4. Seyedarabi A, To TT, Ali S, Hussain S, Fries M, Madsen R, Clausen MH Teixteira S, Brocklehurst K, Pickersgill RW: Structural insights into substrate specificity and the anti beta-elimination mechanism of pectate lyase. Biochemistry 2010, 49(3):539-546.

5. Berensmeier S, Singh SA, Meens J, Buchholz K: Cloning of the pelA gene from Bacillus licheniformis $14 \mathrm{~A}$ and biochemical characterization of recombinant, thermostable, high-alkaline pectate lyase. Appl Microbiol Biotechnol 2004, 64(4):560-567.

6. Agrawal PB, Nierstrasz VA, Klug-Santner BG, Gubitz GM, Lenting HB, Warmoeskerken MM: Wax removal for accelerated cotton scouring with alkaline pectinase. Biotechnol J 2007, 2(3):306-315.

7. Yadav S, Yadav PK, Yadav D, Yadav KDS: Pectin lyase: a Review. Process Biochem 2009, 44(1):1-10

8. Kluskens LD, van Alebeek GJ, Voragen AG, de Vos WM, van der Oost J: Molecular and biochemical characterization of the thermoactive family 1 pectate lyase from the hyperthermophilic bacterium Thermotoga maritima. Biochem J 2003, 370(Pt 2):651-659.

9. Li G, Rao L, Xue Y, Zhou C, Zhang Y, Ma Y: Cloning, expression, and characterization of a highly active alkaline pectate lyase from alkaliphilic Bacillus sp. N16-5. J Microbiol Biotechnol 2010, 20(4):670-677.

10. Ko CH, Tsai CH, Tu J, Tang SH, Liu CC: Expression and thermostability of Paenibacillus campinasensis BL11 pectate lyase and its applications in bast fibre processing. Ann Appl Biol 2011, 158(2):218-225.

11. Soriano M, Blanco A, Diaz P, Pastor Fl: An unusual pectate lyase from a Bacillus sp. with high activity on pectin: cloning and characterization. Microbiology 2000, 146:89-95.

12. Boland WE, Henriksen ED, Doran-Peterson J: Characterization of two Paenibacillus amylolyticus strain 27C64 pectate lyases with activity on highly methylated pectin. App/ Environ Microb 2010, 76(17):6006-6009.

13. Tjalsma H, Bolhuis A, Jongbloed JDH, Bron S, van Dijl JM: Signal peptide-dependent protein transport in Bacillus subtilis: a genome-based survey of the secretome. Microbiol Mol Biol Rev 2000, 64(3):515-547.

14. Andersson H, Vonheijne G: A 30-residue-long "export initiation domain" adjacent to the signal sequence is critical for protein translocation across the inner membrane of Escherichia coli. Proc Natl Acad Sci USA 1991, 88(21):9751-9754.

15. Henrissat B, Heffron SE, Yoder MD, Lietzke SE, Jurnak F: Functional implications of structure-based sequence alignment of proteins in the extracellular pectate lyase superfamily. Plant Physiol 1995, 107(3):963-976.

16. Gummadi SN, Panda T: Purification and biochemical properties of microbial pectinases - a review. Process Biochem 2003, 38(7):987-996.

17. Fang S, Li J, Liu L, Du G, Chen J: Overproduction of alkaline polygalacturonate lyase in recombinant Escherichia coli by a two-stage glycerol feeding approach. Bioresour Technol 2011, 102(22):10671-10678.

18. Liu Y, Chen G, Wang J, Hao Y, Li M, Li Y, Hu B, Lu F: Efficient expression of an alkaline pectate lyase gene from Bacillus subtilis and the characterization of the recombinant protein. Biotechnol Lett 2012, 34(1):109-115.

19. Zhang J, Kang Z, Ling Z, Cao W, Liu L, Wang M, Du G, Chen J: High-leve extracellular production of alkaline polygalacturonate lyase in Bacillus subtilis with optimized regulatory elements. Bioresour Technol 2013, 146:543-548.

20. Wang ZH, Wang Y, Zhang DX, Li JH, Hua ZZ, Do GC, Chen J: Enhancement of cell viability and alkaline polygalacturonate lyase production by sorbitol co-feeding with methanol in Pichia pastoris fermentation. Bioresour Technol 2010, 101(4):1318-1323.

21. Wang H, Li J, Liu L, Li X, Jia D, Du G, Chen J, Song J: Increased production of alkaline polygalacturonate lyase in the recombinant Pichia pastoris by controlling cell concentration during continuous culture. Bioresour Technol 2012, 124:338-346.
22. Zou M, Li X, Shi W, Guo F, Zhao J, Qu Y: Improved production of alkaline polygalacturonate lyase by homologous overexpression pelA in Bacillus subtilis. Process Biochem 2013, 48(8):1143-1150

23. Takao M, Nakaniwa T, Yoshikawa K, Terashita T, Sakai T: Molecular cloning DNA sequence, and expression of the gene encoding for thermostable pectate lyase of thermophilic Bacillus sp. TS 47. Biosci Biotechnol Biochem 2001, 65(2):322-329.

24. Zhang C, Yao J, Zhou C, Mao L, Zhang G, Ma Y: The alkaline pectate lyase PEL168 of Bacillus subtilis heterologously expressed in Pichia pastoris is more stable and efficient for degumming ramie fiber. BMC Biotechnol 2013, 13:26.

25. Zheng Y, Huang CH, Liu W, Ko TP, Xue Y, Zhou C, Guo RT, Ma Y: Crystal structure and substrate-binding mode of a novel pectate lyase from alkaliphilic Bacillus sp. N16-5. Biochem Biophys Res Commun 2012, 420(2):269-274

26. Shevchik VE, Kester HC, Benen JA, Visser J, Robert-Baudouy J, Hugouvieux-Cotte-Pattat N: Characterization of the exopolygalacturonate lyase PelX of Erwinia chrysanthemi 3937. J Bacterio/ 1999, 181(5):1652-1663.

27. Ouattara HG, Reverchon S, Niamke SL, Nasser W: Biochemical properties of pectate lyases produced by three different Bacillus strains isolated from fermenting cocoa beans and characterization of their cloned genes. Appl Environ Microb 2010, 76(15):5214-5220.

28. Xiao ZH, Bergeron H, Grosse S, Beauchemin M, Garron ML, Shaya D, Sulea T, Cygler M, Lau PCK: Improvement of the thermostability and activity of a pectate lyase by single amino acid substitutions, using a strategy based on melting-temperature-guided sequence alignment. Appl Environ Microb 2008, 74(4):1183-1189.

29. Brown IE, Mallen MH, Charnock SJ, Davies GJ, Black GW: Pectate lyase 10A from Pseudomonas cellulosa is a modular enzyme containing a family $2 \mathrm{a}$ carbohydrate-binding module. Biochem J 2001, 355:155-165.

30. Soriano M, Diaz P, Pastor FIJ: Pectate lyase C from Bacillus subtilis: a novel endo-cleaving enzyme with activity on highly methylated pectin. Microbiology 2006, 152:617-625.

31. Ouattara HG, Reverchon S, Niamke SL, Nasser W: Molecular identification and pectate lyase production by Bacillus strains involved in cocoa fermentation. Food Microbiol 2011, 28(1):1-8.

32. Heikinheimo R, Flego D, Pirhonen M, Karlsson MB, Eriksson A, Mae A, Koiv V, Palva ET: Characterization of a novel pectate lyase from Erwinia carotovora subsp. carotovora. Mol Plant Microbe Interact 1995, 8(2):207-217.

33. Yuan $P$, Meng $K$, Shi $P$, Luo H, Huang H, Tu T, Yang P, Yao B: An alkaline-active and alkali-stable pectate lyase from Streptomyces sp. S27 with potential in textile industry. J Ind Microbiol Biotechnol 2012, 39(6):909-915.

34. Zheng LS, Du YM, Zhang JY: Degumming of ramie fibers by alkalophilic bacteria and their polysaccharide-degrading enzymes. Bioresour Technol 2001, 78(1):89-94.

35. Kashayp DR, Vohra PK, Soni SK, Tewari R: Degumming of buel (Grewia optiva) bast fibres by pectinolytic enzyme from Bacillus sp. DT7. Biotechnol Lett 2001, 23(16):1297-1301.

36. Basu S, Saha MN, Chattopadhyay D, Chakrabarti K: Large-scale degumming of ramie fibre using a newly isolated Bacillus pumilus DKS1 with high pectate lyase activity. J Ind Microbiol Biotechnol 2009, 36(2):239-245.

37. Kapoor M, Beg QK, Bhushan B, Singh K, Dadhich KS, Hoondal GS: Application of an alkaline and thermostable polygalacturonase from Bacillus sp. MG-cp-2 in degumming of ramie (Boehmeria nivea) and sunn hemp (Crotalaria juncea) bast fibres. Process Biochem 2001, 36(8-9):803-807.

38. Shipkowski S, Brenchley JE: Characterization of an unusual cold-active beta-glucosidase belonging to family 3 of the glycoside hydrolases from the psychrophilic isolate Paenibacillus sp. strain C7. Appl Environ Microb 2005, 71(8):4225-4232

39. Wang H, Li X, Ma Y, Song J: Characterization and high-level expression of a metagenome-derived alkaline pectate lyase in recombinant Escherichia coli. Process Biochem 2014, 49(1):69-76.

40. Ochman H, Gerber AS, Hartl DL: Genetic applications of an inverse polymerase chain reaction. Genetics 1988, 120(3):621-623.

41. Rombel IT, Sykes KF, Rayner S, Johnston SA: ORF-FINDER: a vector for high-throughput gene identification. Gene 2002, 282(1-2):33-41.

42. de Jong $A$, Pietersma $H$, Cordes $M$, Kuipers OP, Kok J: PePPER: a webserver for prediction of prokaryote promoter elements and regulons. BMC Genomics 2012, 13:299.

43. Abreu-Goodger C, Merino E: RibEx: a web server for locating riboswitches and other conserved bacterial regulatory elements. Nucleic Acids Res 2005, 33(Web Server issue):W690-W692. 
44. Bendtsen JD, Nielsen H, von Heijne G, Brunak S: Improved prediction of signal peptides: SignalP 3.0. J Mol Biol 2004, 340(4):783-795.

45. Edgar RC: MUSCLE: multiple sequence alignment with high accuracy and high throughput. Nucleic Acids Res 2004, 32(5):1792-1797.

46. Solbak Al, Richardson TH, McCann RT, Kline KA, Bartnek F, Tomlinson G, Tan X, Parra-Gessert L, Frey GJ, Podar M, Luginbuhl P, Gray KA, Mathur E, Robertson DE, Burk MJ, Hazlewood GP, Short JM, Kerovuo J: Discovery of pectin-degrading enzymes and directed evolution of a novel pectate lyase for processing cotton fabric. J Biol Chem 2005, 280(10):9431-9438.

doi:10.1186/1472-6750-14-18

Cite this article as: Li et al:: Cloning, expression and characterization

of a pectate lyase from Paenibacillus sp. 0602 in recombinant

Escherichia coli. BMC Biotechnology 2014 14:18.

\section{Submit your next manuscript to BioMed Central and take full advantage of:}

- Convenient online submission

- Thorough peer review

- No space constraints or color figure charges

- Immediate publication on acceptance

- Inclusion in PubMed, CAS, Scopus and Google Scholar

- Research which is freely available for redistribution 